\title{
Methodological adjustment of the accelerated aging test to evaluate the vigor of chia seeds ${ }^{1}$
}

\author{
Aline Klug Radke ${ }^{2 *}$, Fernanda da Motta Xavier ${ }^{2}$, Paulo Eduardo Rocha Eberhardt ${ }^{2}$, \\ Francisco Amaral Villela², Géri Eduardo Meneghello ${ }^{2}$
}

\begin{abstract}
Chia cultivation is expanding in Brazil, but there is still no standardized test to evaluate the quality of the seeds. Therefore, vigor tests that expose seeds to stress conditions must be standardized. This study aimed to establish the methodology for the accelerated aging test in chia seeds. Six chia seed lots with similar germination behavior were used. They were submitted to germination, first germination count, seedling emergence, emergence speed index and accelerated aging tests. Aging periods of 24, 48, and 72 hours were used in the conventional methodology, and also with the use of unsaturated and saturated sodium chloride $(\mathrm{NaCl})$ solutions. The results obtained from the accelerated aging tests revealed tendencies for lot separation similar to the classification of chia seed lots in relation to the physiological potential obtained in the preliminary quality tests. The accelerated aging test can be used to evaluate the physiological potential of chia seeds by using water or unsaturated saline solution. In the conventional test (water), the seeds should be exposed for 24 hours. When using unsaturated saline solution, the exposure time must be of 48 hours.
\end{abstract}

Index terms: Salvia hispanica L., germination, saline solution, vigor.

\section{Ajuste metodológico do teste de envelhecimento acelerado para avaliação do vigor de sementes de chia}

\begin{abstract}
RESUMO - O cultivo de chia está em expansão no Brasil, e ainda não existem testes padronizados para avaliação da qualidade das sementes para esta cultura. Por isso, existe a necessidade de padronização de testes de vigor que exponham as sementes a condições de estresse. O presente trabalho objetivou estabelecer a metodologia do teste de envelhecimento acelerado para sementes de chia. Foram utilizados seis lotes de sementes de chia com similaridade quanto à germinação. Eles foram submetidos aos testes de germinação, primeira contagem de germinação, emergência de plântulas, índice de velocidade de emergência, e envelhecimento acelerado. Foram empregados períodos de envelhecimento de 24,48 e 72 horas, na metodologia convencional, e com o uso de soluções salina não saturada e saturada de cloreto de sódio ( $\mathrm{NaCl})$. Os resultados obtidos nos testes de envelhecimento acelerado revelaram tendências semelhantes na separação dos lotes, quando comparados com a classificação dos lotes de sementes de chia em relação ao potencial fisiológico obtidos nos testes preliminares. O teste de envelhecimento acelerado pode ser empregado na avaliação do potencial fisiológico de sementes de chia, utilizando-se água ou solução salina não saturada. No teste convencional (água), as sementes devem ficar expostas por 24 horas. Ao utilizar solução salina não saturada, o tempo deve ser de 48 horas.
\end{abstract}

Termos para indexação: Salvia hispanica L., germinação, solução salina, vigor.

\section{Introduction}

Chia (Salvia hispanica L.) is an herbaceous, annual species from the family Lamiaceae (Coelho and Salas-
Mellado, 2014), which is distributed in the temperate zones of Mexico (Martínez-Gordillo et al., 2013). In Brazil, its cultivation is still recent, and in the south region of the country some farmers started to invest in crops, but information is

\footnotetext{
${ }^{1}$ Subimitted on 11/25/2017. Accepted for publication on 03/01/2018.

${ }^{2}$ Departamento de Fitotecnia, Faculdade de Agronomia Eliseu Maciel, Universidade Federal de Pelotas, Caixa postal 354, $96010-900$ - Pelotas, RS, Brasil.

*Corresponding author <alinekradke@hotmail.com>
} 
still scarce (Migliavacca et al., 2014). Chia seeds are the plant natural resource with the highest fatty acid content known to date, emphasis given to alpha linoleic (omega-3) and linoleic (omega-6) acids, essential to humans, whose organism is not capable of producing them. So, they must be provided by dietary means (Jamboonsri et al., 2012). Once the use of chia seeds in human food increases, the demand for cultivation areas grows. In south Brazil, the productivity has the potential to reach $800 \mathrm{~kg}$. ha ${ }^{-1}$ (Migliavacca et al., 2014), which reinforces the necessity of monitoring seed quality.

The physiological parameter of seed quality is determined by the germination test, which is conducted under favorable conditions that allow seeds from the lots to express their maximum germination capacity (Pereira et al., 2011). However, the results can be overestimated and may not express the true quality of the lot. Therefore, vigor tests have been used, because they allow to perceive differences in the physiological potential among seed lots that are not detectable by the germination test.

Therefore, it is necessary to improve seed vigor tests, especially in order to obtain consistent information, preferably within a relatively short time (Pereira et al., 2011).

In this sense, seed vigor tests and the very concept of vigorous seeds are used in seed production programs as an important strategy for controlling quality, since they help to guarantee an adequate positioning of the plant population in the field (Silva et al., 2017).

Among the proposed methods, the accelerated aging test is promising and shows practical interest (Lima et al., 2006), besides being recognized as one of the most used to assess the physiological potential of seeds of several species, such as lettuce and eggplant (Santos et al., 2011; Lopes et al., 2013), providing highly consistent information (Tunes et al., 2013). The test is based on the artificial acceleration of seed deterioration through the exposure to high temperature and relative humidity conditions, which are considered as the environmental factors that most affect the intensity and speed of deterioration (Marcos-Filho, 2015b).

So, the accelerated aging test is frequently used in quality control programs of seed lots, because it is efficient in evaluating the physiological potential, and also provides relatively reliable information on the storage potential of seeds and on the emergence potential of seedlings (Rodo et al., 2000).

In Brazil, there is no methodology established to perform the accelerated aging test on chia seeds. Besides, considering the increase in cultivation and commercialization of this species, the evaluation of seed quality is fundamental for the success of the culture.

Therefore, the objective of this work was to establish the methodology to perform the accelerated aging test on chia seeds.

\section{Material and Methods}

The study was conducted at the Laboratory of Seed Analysis and in the greenhouse of the Faculdade de Agronomia Eliseu Maciel, Universidade Federal de Pelotas (FAEM/UFPel), from March 2017 until October 2017. Six lots of chia seeds were used, provided by farmers who grow the species in the Northwest region of the state of Rio Grande do Sul (RS). The seeds were characterized as for their quality according to the following tests.

Moisture content - it was determined by the oven method at $105 \pm 3{ }^{\circ} \mathrm{C}$ for 24 hours. The results were expressed as percentage, in wet basis (Brasil, 2009).

Germination - 200 seeds were used. They were separated in four replications, distributed on two blotting paper sheets, moistened with water in the proportion of 2.5 times the dry paper weight. Then, they were placed in gerboxes (transparent plastic boxes with $11 \times 11 \times 3.5 \mathrm{~cm}$ dimensions), inside a germinator at $20{ }^{\circ} \mathrm{C}$. Counts were performed after 4 and 7 days (adapted from Stefanello et al., 2015). The results were expressed as percentage of normal seedlings per lot.

First germination count - it was carried out jointly with the germination test, and the counts were done 4 days after the test setup.

Seedling emergence - four replications with 50 seeds each were used. They were distributed on plastic trays containing vermiculite as substrate. Substrate moistening was performed whenever necessary. The trays were maintained inside greenhouse without temperature nor relative humidity control. Outside the greenhouse, the mean temperature in March 2017 was $21.6^{\circ} \mathrm{C}$, and the maximum and minimum temperatures were $27.3{ }^{\circ} \mathrm{C}$ and $15.9{ }^{\circ} \mathrm{C}$, respectively. The average relative humidity was $83.2 \%$, and the average solar radiation was $416.2 \mathrm{cal}^{\mathrm{cm}} \mathrm{cm}^{-2}$.day ${ }^{-1}$, according to data provided by the Monthly Climatological Bulletin (March 2017), from Embrapa Clima Temperado, for the coordinates $31^{\circ} 41^{\prime} \mathrm{S}, 52^{\circ} 26^{\prime} \mathrm{W}$ (Brasil, 2018). The evaluations were performed through daily counts of the number of emerged seedlings until stabilization.

Emergence speed index (ESI) - it was carried out together with the seedling emergence test. From the counts of the daily-emerged seedlings, the speed index was calculated as proposed by Maguire (1962).

Conventional accelerated aging $-6 \mathrm{~g}$ of seeds divided into four replications of $1.5 \mathrm{~g}$ (so they formed a single layer over the screen) were used. The seeds were distributed evenly on a metal screen inside transparent plastic boxes $(11 \times 11 \times 3.5 \mathrm{~cm})$ containing $40 \mathrm{~mL}$ of distilled water. Due to seed dimensions, tulle was put between them and the screen to prevent seeds from 
falling on the bottom of the box. The seeds were incubated in a BOD at $41^{\circ} \mathrm{C}$ for 24,48 , and 72 hours. After the aging period, they were submitted to the germination test, and the evaluation was carried out 4 days after sowing (Marcos-Filho, 2015b).

Accelerated aging using unsaturated saline solution - the procedure was similar to the one described for the conventional accelerated aging test, but $40 \mathrm{~mL}$ of unsaturated saline solution was used instead of water $(11 \mathrm{~g}$ of $\mathrm{NaCl}$ for $100 \mathrm{~mL}$ of distilled water), as proposed by Costa et al. (2008).

Accelerated aging using saturated saline solution - the procedure was similar to the one described for the conventional accelerated aging test, but $40 \mathrm{~mL}$ of saturated saline solution was used instead of water $(40 \mathrm{~g}$ of $\mathrm{NaCl}$ for $100 \mathrm{~mL}$ of distilled water), as proposed by Marcos-Filho (2015b).

Simultaneously to the accelerated aging tests, the moisture content of the seeds was determined after each aging period, in order to check the uniformity of the test conditions, as suggested by Marcos-Filho (1999).

The experimental design was completely ized, and the treatments corresponded to the six lots, with four replications. The data obtained were analyzed as for normality and homoscedasticity by the Shapiro-Wilk and the Harley tests, respectively. They indicated the necessity to submit the data expressed as percentage through the arcsine $(\sqrt{ }(x / 100))$ transformation. For the remaining data, the transformation was not necessary. After that, the means were submitted to the variation analysis (ANOVA) and compared by the Tukey's test at 5\% significance. The statistic software Winstat was used to assist the analyses (Machado and Conceição, 2002).

\section{Results and Discussion}

For the initial moisture content (Table 1), all six lots showed similar results, and lot 2 presented the lowest moisture content $(6.9 \%)$, whereas lot 5 showed the highest value $(7.2 \%)$. According to Tunes et al. (2011), if the moisture content of the seeds is relatively low, as observed in the chia seed lots, the physiological quality tests results are expected to be more reliable. The uniformity of the initial moisture content of seeds is a key factor for standardization of tests and determinations to be performed (Martins et al., 2014). This occurs because seeds with higher moisture content, within certain limits, are more affected by the accelerated aging conditions, due to differences in moistening speed and seed deterioration during aging (Marcos-Filho and Novembre, 2009; Tunes et al., 2012).

The results concerning the initial quality of the chia seed lots (Table 1) showed that there was no significant difference among them, according to the germination test. However, by the first germination count test, lot 1 presented values significantly lower than the lot 6 . As stated by Haesbaert et al. (2017), most of the times the germination test overestimates the physiological potential of seeds, since it is conducted in favorable conditions of temperature and relative humidity. So, it has limitations in evaluating the potential of seedling emergence in field.

Therefore, since no differences in the germination percentage were observed, the application of vigor tests in seed lots is justifiable, because one of the goals of these tests is to reveal differences in the physiological potential that were not detected by the germination test (Marcos-Filho, 2015b).

The emergence test in greenhouse showed two-level stratification in chia seed lots: high-vigor lots 3 and 6, and low-vigor lots 1, 2, 4 and 5. So, the method allowed the identification of the first manifestations of seed deterioration. According to Bewley et al. (2013), the reduction in the percentage of seedling emergence is a consequence of the natural aging process of seeds, which is related to damages in the biomembrane system. In addition, it is used as a reference test to evaluate the efficiency of vigor tests in differentiating lots that show similar responses in the germination test (Marcos-Filho, 1999). Therefore, many companies and seed producers are using this test, because it is the one the most closely resembles the actual farmers' conditions.

The determination of the emergence speed index evidenced the superiority of lots 3 and 6 , but did not effectively differentiated the other lots into vigor levels. This suggests that this test has sensibility limitations for separating seed lots by their physiological potential (Amaro et al., 2014). Thus, Marcos-Filho (2015b) also reinforces the importance of using more than one test to estimate seed vigor, due to the variation of efficiency of the available procedures.

Table 2 shows the mean water content results after accelerated aging performed with and without $\mathrm{NaCl}$ solution,

Table 1. Initial moisture content (MC), germination (G), first germination count (FGC), seedling emergence (E), and emergence speed index (ESI) of six lots of chia seeds.

\begin{tabular}{cccccc}
\hline Lots & MC $(\%)$ & G $(\%)$ & FGC $(\%)$ & E (\%) & ESI \\
\hline 1 & 7.0 & $90 \mathrm{~A}$ & $81 \mathrm{~B}$ & $81 \mathrm{~B}$ & $8.4 \mathrm{~B}$ \\
2 & 6.9 & $91 \mathrm{~A}$ & $86 \mathrm{AB}$ & $87 \mathrm{~B}$ & $9.8 \mathrm{AB}$ \\
3 & 7.0 & $96 \mathrm{~A}$ & $91 \mathrm{AB}$ & $96 \mathrm{~A}$ & $10.4 \mathrm{~A}$ \\
4 & 7.0 & $90 \mathrm{~A}$ & $83 \mathrm{AB}$ & $85 \mathrm{~B}$ & $9.3 \mathrm{AB}$ \\
5 & 7.2 & $93 \mathrm{~A}$ & $90 \mathrm{AB}$ & $84 \mathrm{~B}$ & $9.2 \mathrm{AB}$ \\
6 & 7.1 & $96 \mathrm{~A}$ & $92 \mathrm{~A}$ & $96 \mathrm{~A}$ & $10.5 \mathrm{~A}$ \\
\hline $\mathrm{CV}(\%)$ & & 3.16 & 5.22 & 4.09 & 7.21 \\
\hline
\end{tabular}

*Means followed by the same uppercase letter in the column do not differ according to the Tukey's test at $5 \%$ probability. 
at $41^{\circ} \mathrm{C}$. These data were not statistically analyzed, and served for the characterization of the seed lots after they remained under the accelerated aging conditions, and also as an indicator of uniformity (or lack of it) of the conditions under which the test was performed. The moisture content of seeds after aging is one of the most important indicator of the test uniformity conditions, and variations of up to 3 to $4 \%$ among lots are acceptable (Marcos-Filho and Novembre, 2009).

The moisture content of the chia seeds went up as the aging period increased, for all methods used (Table 2). When seeds were submitted to the conventional accelerated aging method, the moisture content increase was proportional to the exposure time. This result corroborates with the studies of Barbosa et al. (2011) and Torres et al. (2014) on lettuce and okra, in which they verified a higher absorption speed and a greater quantity of water absorbed in seeds aged in conventional solution.

However, the use of $\mathrm{NaCl}$ saturate solution promoted a greater reduction in water absorption speed by chia seeds during the aging period, in comparison with the coventional and the unsaturated solution methods. This result is similar to those obtained by Lemes et al. (2015) in a study with bermudagrass seeds. They observed that the use of saline solutions inside aging chamber led to a lower water absorption by the seeds during the accelerated aging test, compared to the conventional method.

Using saturated saline solution kept the relative humidity inside the plastic boxes lower $(76 \%)$ than if water was used $(100 \%)$, and seeds hydration occurred slowly, i.e., water absorption was slowed down, as also verified by Jianhua and McDonald (1996). Besides, the rate and intensity of water absorption by the seeds may influence the accelerated aging test outcome (Marcos-Filho, 2015a).

Seed moisture content was very similar in all six lots submitted to accelerated aging with $\mathrm{NaCl}$ saturate solution. In this method, seeds absorb water more slowly, which allows the occurrence of lower moisture contents than in other methods.

Based on the percentage of normal seedlings got in the germination test after accelerated aging period with water or saline solutions (Table 3), it was possible to classify the chia seed lots according to vigor levels.

In addition, regardless of time the seeds were exposed to the test conditions, whether with water or saline solution, it was possible to confirm the highest vigor in lots 3 and 6 ; the intermediate in lots 2, 4 and 5 ; and the lowest in lot 1 , in relation to the other lots analyzed.

As in the seedling emergence test, chia seeds from lots 3 and 6 submitted to the traditional aging test for 24 hours. This

Table 2. Moisture content (\%) of six chia seed lots, after three periods of accelerated aging, in the conventional method, with unsaturated saline solution (USS) and with saturated saline solution (SSS).

\begin{tabular}{|c|c|c|c|c|c|c|c|c|c|}
\hline \multirow{2}{*}{ Lots } & \multicolumn{3}{|c|}{ Conventional } & \multicolumn{3}{|c|}{ USS } & \multicolumn{3}{|c|}{ SSS } \\
\hline & $24 \mathrm{~h}$ & $48 \mathrm{~h}$ & $72 \mathrm{~h}$ & $24 \mathrm{~h}$ & $48 \mathrm{~h}$ & $72 \mathrm{~h}$ & $24 \mathrm{~h}$ & $48 \mathrm{~h}$ & $72 \mathrm{~h}$ \\
\hline 1 & 13.0 & 14.9 & 16.2 & 11.9 & 11.3 & 12.9 & 7.1 & 7.3 & 7.5 \\
\hline 2 & 13.9 & 15.7 & 16.4 & 11.1 & 11.7 & 13.0 & 7.1 & 7.5 & 7.3 \\
\hline 3 & 11.6 & 13.3 & 17.9 & 13.1 & 11.3 & 12.4 & 7.2 & 7.3 & 7.5 \\
\hline 4 & 13.9 & 15.2 & 16.8 & 13.5 & 10.6 & 14.2 & 7.1 & 7.1 & 7.3 \\
\hline 5 & 12.0 & 13.0 & 17.4 & 11.1 & 11.1 & 15.0 & 7.3 & 7.9 & 7.4 \\
\hline 6 & 13.9 & 15.1 & 17.0 & 13.3 & 10.9 & 11.9 & 7.2 & 8.0 & 8.1 \\
\hline
\end{tabular}

Table 3. Mean percentage (\%) of normal seedlings obtained from the germination test, after conventional accelerated aging test, with unsaturated saline solution (USS), and with saturated saline solution (SSS) for 24, 48 and 72 hours.

\begin{tabular}{|c|c|c|c|c|c|c|c|c|c|}
\hline \multirow{2}{*}{ Lots } & \multicolumn{3}{|c|}{ Conventional } & \multicolumn{3}{|c|}{ USS } & \multicolumn{3}{|c|}{ SSS } \\
\hline & $24 \mathrm{~h}$ & $48 \mathrm{~h}$ & $72 \mathrm{~h}$ & $24 \mathrm{~h}$ & $48 \mathrm{~h}$ & $72 \mathrm{~h}$ & $24 \mathrm{~h}$ & $48 \mathrm{~h}$ & $72 \mathrm{~h}$ \\
\hline 1 & $84 \mathrm{~B}$ & $80 \mathrm{C}$ & $78 \mathrm{~B}$ & $86 \mathrm{AB}$ & $74 \mathrm{~B}$ & $69 \mathrm{C}$ & $81 \mathrm{D}$ & $83 \mathrm{C}$ & $80 \mathrm{C}$ \\
\hline 2 & $89 \mathrm{~B}$ & $89 \mathrm{AB}$ & $80 \mathrm{~B}$ & $90 \mathrm{AB}$ & $80 \mathrm{~B}$ & $86 \mathrm{~A}$ & $88 \mathrm{C}$ & $87 \mathrm{BC}$ & $86 \mathrm{C}$ \\
\hline 3 & $96 \mathrm{~A}$ & $94 \mathrm{~A}$ & $91 \mathrm{~A}$ & $93 \mathrm{AB}$ & $91 \mathrm{~A}$ & $89 \mathrm{~A}$ & $94 \mathrm{AB}$ & $96 \mathrm{~A}$ & $96 \mathrm{~A}$ \\
\hline 4 & $87 \mathrm{~B}$ & $84 \mathrm{BC}$ & $83 \mathrm{AB}$ & $88 \mathrm{AB}$ & $77 \mathrm{~B}$ & $76 \mathrm{~B}$ & $90 \mathrm{BC}$ & $87 \mathrm{BC}$ & $87 \mathrm{BC}$ \\
\hline 5 & $87 \mathrm{~B}$ & $82 \mathrm{BC}$ & $91 \mathrm{~A}$ & $85 \mathrm{AB}$ & $78 \mathrm{~B}$ & $79 \mathrm{~B}$ & $89 \mathrm{BC}$ & $88 \mathrm{~B}$ & $86 \mathrm{C}$ \\
\hline 6 & $96 \mathrm{~A}$ & $93 \mathrm{~A}$ & $87 \mathrm{AB}$ & $94 \mathrm{~A}$ & $90 \mathrm{~A}$ & $89 \mathrm{~A}$ & $96 \mathrm{~A}$ & $95 \mathrm{~A}$ & $95 \mathrm{AB}$ \\
\hline $\mathrm{CV}(\%)$ & 3.51 & 3.89 & 5.45 & 459 & 3.52 & 3.24 & 2.61 & 1.99 & 4.48 \\
\hline
\end{tabular}

* Means followed by the same uppercase letter in the column do not differ according to the Tukey's test at $5 \%$ probability. 
is different from the results of Lopes et al. (2013) and Kikuti and Marcos-Filho (2008) on eggplant and cauliflower seeds, respectively, in which they concluded that the accelerated aging test can be conducted by the traditional method, for 48 hours at $41^{\circ} \mathrm{C}$.

On the other hand, by conducting the accelerating aging test with unsaturated saline solution for 48 hours, it was possible to classify the chia seed lots, as in the seedling emergence test, into two levels of vigor: the high-vigor lots 3 and 6, and the low-vigor lots 1, 2, 4 and 5. In this sense, Marcos-Filho (2015b) points out that, in order to perform a reliable vigor test, it should provide reproducible and fieldrelated emergence results.

Also, the accelerated aging test using saline solution allowed the classification of the chia seed lots only into two vigor levels, for all exposure periods, highlighting the lowest vigor for lots 1,2, 4 and 5, and the highest vigor for the remaining others. This can be probably explained by the nature of the lots studied, and also by the particularities of the test in this species, which is still poorly studied, so its behavior is not completely understood. In this very sense, in a study performed with clove basil seeds (Ocimum gratissimum L.), Lima et al. (2006) verified that intervals of 36 and 48 hours of accelerated aging at $42{ }^{\circ} \mathrm{C}$ combined with saline solution were effective in evaluating their physiological quality.

In general, the results obtained in the accelerated aging tests (Table 3) showed similar lot separation trends when compared to the classification, according to the physiological potential got from the preliminary tests (Table 1), although small variations were noticed.

The temperature of $41^{\circ} \mathrm{C}$ for periods of 24 and 48 hours in the conventional accelerated aging, and in the modified method using unsaturated saline solution, respectively, were the most suitable conditions to perform the test in chia seeds. These data can be useful to identify lots more likely to present an adequate performance, when the environmental conditions are not ideal. Therefore, seed vigor tests give additional information to the germination test, which facilitates the decision making about the destination of the lots, based on their physiological potential.

\section{Conclusions}

The accelerated aging test can be used to evaluate the physiological potential of chia seeds by using water or unsaturated saline solution.

In the conventional test (water), the seeds should be exposed for 24 hours. If unsaturated saline solution is used, the time must be 48 hours.

\section{Acknowledgments}

To the Conselho Nacional de Desenvolvimento Científico e Tecnológico - CNPq, for the scholarship granted.

\section{References}

AMARO, H.T.R.; DAVID, A.M.S.S.; NETA, I.C.S.; ASSIS, M.O.; ARAÚJO, E.F.; ARAÚJO, R.F. Teste de envelhecimento acelerado em sementes de crambe (Crambe abyssinica Hochst), cultivar FMS Brilhante. Revista Ceres, v.61, n.2, p.202-208, 2014. http://www.scielo. br/scielo.php?pid=S0034-737X2014000200007\&script=sci_arttext

BARBOSA, M.R.; COSTA, D.S.; SÁ, M.E. Envelhecimento acelerado em sementes de alface. Ciência Rural, v.41, n.11, p.1899-1902, 2011. http://www.scielo.br/scielo.php?script=sci_ arttext\&pid=S0103-84782011001100008

BRASIL. Ministério da Agricultura, Pecuária e Abastecimento. Regras para análise de sementes. Secretaria de Defesa Agropecuária. Brasília: Mapa/ACS, 2009. 399p. http://www.agricultura.gov. br/assuntos/insumos-agropecuarios/arquivos-publicacoesinsumos/2946_regras_analise_sementes.pdf

BRASIL. Empresa Brasileira de Pesquisa Agropecuária - Embrapa - Clima Temperado. Dados meteorológicos de Pelotas/RS. Boletim Climatológico Mensal. http://agromet.cpact.embrapa.br/online/ reports/marco2017.pdf Accessed on: 01 mar. 2018.

BEWLEY, J.D.; BRADFORD, K.J.; HILHORST, H.W.M.; NONOGAKI, H. Seeds - physiology of development, germination and dormancy. 3.ed. New York: Springer, 2013. 392p.

COELHO, M.S.; SALAS-MELLADO, M.L.M.Revisão:Composição química, propriedades funcionais e aplicações tecnológicas da semente de chia (Salvia hispanica L) em alimentos. Brazilian Journal of Food Technology, v.17, n.4, p.259-268, 2014. http://www.scielo. br/scielo.php?pid=S1981-67232014000400259\&script=sci_arttext

COSTA, C.J.; TRZECIAK, M.B.; VILLELA, F.A. Potencial fisiológico de sementes de brássicas com ênfase no teste de envelhecimento acelerado. Horticultura Brasileira, v.26, n.2, p.144148, 2008. http://www.scielo.br/pdf/hb/v26n2/03.pdf

HAESBAERT, F.M.; LOPES, S.J.; MERTZ, L.M.; LÚCIO, A.D.; HUTH, C. Tamanho de amostra para determinação da condutividade elétrica individual de sementes de girassol. Bragantia, v.76, n.1, p.54-61, 2017. http://www.scielo.br/scielo.php?pid=S0006$87052017000100054 \&$ script $=$ sci_abstract\&tlng=pt

JAMBOONSRI, W.; PHILLIPS, T.D.; GENEVE, R.L.; CAHILL, J.P.; HILDEBRAND, D.F. Extending the range of an ancient crop, Salvia hispanica L.- - a new $\omega 3$ source. Genetic Resources and Crop Evolution, v.59, n.2, p.171-178, 2012. https://link.springer.com/ article/10.1007\%2Fs 10722-011-9673-x

JIANHUA, Z.; McDONALD, M.B. The saturated salt accelerated aging test for small seeds crops. Seed Science and Techology, v.25, n.1, p.123-131, 1996. 
KIKUTI, A.L.P.; MARCOS-FILHO, J. Physiological potential of cauliflower seeds. Scientia Agricola, v.65, n.4, p.374-380, 2008. http://www.scielo.br/pdf/sa/v65n4/08.pdf

LEMES, E.S.; OLIVEIRA, S.; ALMEIDA, A.S.; MENEGHELLO, G.E.; GEWEHR, E.; TUNES, L.M. Testes de vigor para avaliação da qualidade de sementes de grama-bermuda. Revista de la Facultad de Agronomía, v.114, n.2, p.185-192, 2015. http://sedici.unlp.edu. $\mathrm{ar} /$ bitstream/handle/10915/51294/Documento_completo.pdf-PDFA. pdf? sequence $=1$

LIMA, C.B.; ATHANÁZIO, J.C.; BELLETTINI, N.M.T. Germinação e vigor de sementes de alfavaca-cravo (Ocimum gratissimum $\mathrm{L}$.) submetidas ao envelhecimento acelerado. Semina: Ciências Agrárias, v.27, n.2, p.159-170, 2006. http://www.redalyc.org/html/4457/445744080002/

LOPES, M.D.M.; SILVA, C.B.D.; VIEIRA, R.D. Physiological potential of eggplant seeds. Journal of Seed Science, v.35, n.2, p.225-230, 2013. http://www.scielo.br/scielo.php?script=sci_ arttext\&pid $=$ S2317-15372013000200012

MACHADO, A.; CONCEIÇÃO, A.R. Programa estatístico WinStat sistema de análise estatístico para Windows. Versão 2.0. Pelotas: UFPel, 2002.

MAGUIRE, J.D. Speed of germination-aid in selection and evaluation for seedling emergence and vigor. Crop Science, v.2, n. 1, p.176-177, 1962.

MARCOS-FILHO, J. Teste de envelhecimento acelerado. In: KRZYZANOWSKI, F.C.; VIEIRA, R.D.; FRANÇA-NETO, J.B. (eds). Vigor de sementes: conceitos e testes. Londrina: ABRATES. 1999. p.3.1-3.11.

MARCOS-FILHO, J.; NOVEMBRE, A.D.L.C. Avaliação do potencial fisiológico de sementes de hortaliças. In: NASCIMENTO, W.M. (Ed.). Tecnologia de sementes de hortaliças. Brasília: Embrapa Hortaliças, 2009. p.185-246.

MARCOS-FILHO, J Seed vigor testing: an overview of the past, present and future perspective. Scientia Agricola, v.72, n.4, p.363-374, 2015a. http://www.scielo.br/scielo.php?script=sci arttext\&pid=S0103-90162015000400363

MARCOS-FILHO, J. Avaliação do potencial fisiológico de sementes. In: MARCOS-FILHO, J. Fisiologia de sementes de plantas cultivadas. 2 ed. Londrina, PR: Abrates, 2015b. p.615-659

MARTÍNEZ-GORDILLO， M.; FRAGOSO-MARTÍNEZ， I.; GARCÍA-PEÑA, M.R.; MONTIEL, O. Géneros de Lamiaceae de México, diversidad y endemismo. Revista Mexicana de Biodiversidad, v.84, n.1, p.30-86, 2013. http://www.scielo.org.mx/ pdf/rmbiodiv/v84n1/v84n1a4.pdf

MARTINS, C.C.; SILVA, N.; MACHADO, C.G. Testes para a seleção de populações de cenoura visando ao vigor e à longevidade das sementes. Ciência Rural, v.44, n.5, p. 768-774, 2014. http:// www.scielo.br/scielo.php?script $=$ sci arttext\&pid $=$ S $0103-$ $84782014000500002 \& \operatorname{lng}=$ en\&nrm $=$ iso
MIGLIAVACCA, A.R.; SILVA, B.R.T.; VASCONCELOS, S.L.A.; FILHO, M.W.; BAPTISTELLA, C.L.J. O cultivo da chia no Brasil: futuro e perspectivas. Journal of Agronomic Sciences, v.3, n.especial, p.161-179, 2014.

PEREIRA, M.F.S.; TORRES, S.B.; LINHARES, P.C.F.; PAIVA, A.C.C.; PAZ, A.E.S.; DANTAS, A.H. Qualidade fisiológica de sementes de coentro [Coriandrum sativum (L.)]. Revista Brasileira de Plantas Medicinais, v.13, n. spe, p.518-522, 2011. http://www.scielo.br/scielo. php?pid=S1516-05722011000500002\&script=sci_abstract\&tlng $=\mathrm{pt}$

RODO, A.B.; PANOBIANCO, M.; MARCOS-FILHO, J. Metodologia alternativa do teste de envelhecimento acelerado para sementes de cenoura. Scientia Agrícola, v.57, n.2, p.289-292, 2000. http://www.scielo. br/scielo.php?script=sci_arttext\&pid=S0103-90162000000200015

SANTOS, F.D.; TRANI, P.E.; MEDINA, P.F.; PARISI, J.J.D. Accelerated aging test for evaluating lettuce and endive seed quality. Revista Brasileira de Sementes, v.33, n.2, p.322-330, 2011. http://www.scielo.br/scielo. php?pid=S0101-31222011000200015\&script $=$ sci_arttext

SILVA, C.B.; BARBOSA, R.M.; VIEIRA, R.D. Accelerated aging as vigor test for sunn hemp seeds. Ciência Rural, v.47, n.1, e20151527, 2017. http://www.scielo.br/scielo.php?script=sci arttext\&pid=S0103-84782017000100402

STEFANELLO, R.; NEVES, L.; ABBAD, M.; VIANA, B. Germination and vigor of chia seeds (Salvia hispanica L. - Lamiaceae) under different temperatures and light conditions. Revista Brasileira de Plantas Medicinais, v.17, n.4, p.1182-1186, 2015. http://www.scielo. br/scielo.php?pid=S1516-05722015000701182\&script=sci_arttext

TORRES, S.B.; SILVA, F.G.; GOMES, M.D.A.; BENEDITO, C.P.; PEREIRA, F.E.C.B.; SILVA, E.C. Diferenciação de lotes de sementes de quiabo pelo teste de envelhecimento acelerado. Ciência Rural, v.44, n.12, p.2103-2110, 2014. http://www.scielo.br/scielo. php? script $=$ sci_arttext\&pid=S0103-84782014001202103\&lng=en \&nrm $=$ iso\& $\&$ lng $=p t$

TUNES, L.M.; PEDROSO, D.C.; BADINELLI, P.G.; TAVARES, L.C.; RUFINO, C.A.; BARROS, A.C.S.A.; MUNIZ, M.F.B. Envelhecimento acelerado em sementes de azevém com e sem solução salina saturada. Ciência Rural, v.41, n.1, p.33-37, 2011. http://www.scielo.br/scielo. php?script=sci_arttext\&pid=S0103-84782011000100006

TUNES, L.M.; TAVARES, L.C.; RUFINO, C.A.; BARROS, A.C.S.A.; MUNIZ, M.F.B.; DUARTE, V.B. Envelhecimento acelerado em sementes de brócolis (Brassica oleracea L. var. italica Plenk). Bioscience Journal, v.28, n.2, p.173-179, 2012. http://www. seer.ufu.br/index.php/biosciencejournal/article/view/11636/8475

TUNES, L.M.; PEDROSO, D.C.; GADOTTI, G.I.; MUNIZ, M.F.B.; BARROS, A.C.S.A.; VILLELA, F.A. Accelerated aging to assess parsley seed vigor. Horticultura Brasileira, v.31, n.3, p.457-460, 2013. http://www.scielo.br/scielo.php?pid=S010205362013000300018\&script=sci_arttext 